\title{
ANALISIS BUKU TEKS KURIKULUM 2013 SEBAGAI SUMBER BELAJAR PENDIDIKAN KEWARGANEGARAAN PADA SISWA KELAS VII SMP NEGERI 2 SAYAN KABUPATEN MELAWI
}

\author{
Dada Suhaida ${ }^{1}$, Ade Suhandra ${ }^{2}$ \\ ${ }^{1}$ Program Studi Pendidikan Pancasila dan Kewarganegaraan, IKIP PGRI Pontianak \\ ${ }^{2}$ Sekolah Menengah Pertama Negeri 2 Sayan Kabupaten Melawi \\ 1e-mail: civic.link@yahoo.com
}

\begin{abstract}
Abstrak
Penelitian ini difokuskan pada "Analisis Buku Teks Kurikulum 2013 sebagai Sumber Belajar Pendidikan Kewarganegaraan pada Siswa Kelas VII SMP Negeri 2 Syan Kabupaten Melawi”. Tujuan penelitian ini; (1) isi materi buku teks Kurikulum 2013 sebagai sumber belajar siswa kelas VII SMP Negeri 2 Sayan Kabupaten Melawi (2) manfaat buku teks Kurikulum 2013 sebagai sumber belajar siswa kelas VII SMP Negeri 2 Sayan Kebupaten Melawi. Metode penelitian menggunakan kualitatif deskriptif. Teknik pengumpul data yang digunakan teknik komunikasi langsung, teknik observasi tidak langsung, dan teknik dokumenter. Alat pengumpul data yang digunakan yakni, panduan wawancara, panduan observasi, dan dokumentasi. Hasil penelitian menujukkan bahwa; (1) isi materi buku teks Kurikulum 2013 sebagai sumber belajar siswa siswa kelas VII SMP Negeri 2 Sayan Kabupaten Melawi yaitu kesesuaian materi dengan standar Kompetensi (SK) dan Kompetensi Dasar (KD), kesesuaian materi dengan kurikulum, keakuratan materi, mendorong keingintahuan siswa, subtansi keilmuwan dan life skill, serta pengayaan (2) manfaat buku teks Kurikulum 2013 sebagai sumber belajar siswa kelas VII Negeri 2 Sayan Kabupaten Melawi yakni, sebagai bahan belajar yang serius, sebagai bahan ajar yang mudah, bagi guru buku teks berarti keamanan, pentunjuk dan bantuan dalam proses pembelajaran.
\end{abstract}

Kata kunci: Buku Teks Kurikulum 2013, Sumber Belajar, Pendidikan Kewarganegaraan

\begin{abstract}
This study focuses on "Analysis of the 2013 Curriculum Text Book as a Learning Source for Citizenship Education in Class VII Students of the Syan State Middle School 2 Melawi District". The purpose of this study; (1) the contents of the 2013 Curriculum textbook as a learning resource for class VII students of Sayan Middle School 2 Melawi Regency (2) the benefits of the 2013 Curriculum textbook as a learning resource for class VII students of SMP Negeri 2 Sayan Melawi Regency. The research method uses descriptive qualitative. Data collection techniques used are direct communication techniques, indirect collection techniques, and documentary techniques. Data collection tools used are, interview guides, observation guides, and documentation. The results of the study show that; (1) the contents of the 2013 Curriculum textbook as a learning resource for class VII students of Sayan Melawi District 2 Middle School, namely the suitability of materials with Competency (SK) and Basic Competency (KD) standards, material suitability with curriculum, accuracy materials, student curiosity material, scientific substance and life skills, as well as enrichment (2) Benefits of the 2013 Curriculum textbook as a learning resource for class VII students of State 2 of Sayan Melawi Regency, that is, as a serious learning material, as an easy teaching material, for teachers of textbooks about safety, guidance and assistance in learning process.
\end{abstract}

Keywords: Learning Model, Character Education, Civic Education

\section{PENDAHULUAN}

Buku memiliki peranan penting dalam proses pembelajaran dan pengembangan ilmu pengetahuan, buku merupakan salah satu sumber bahan ajar. Ilmu pengetahuan, informasi, dan hiburan dapat diperoleh dari buku, oleh karena itu, buku merupakan komponen wajib yang harus ada di lembaga pendidikan baik lembaga formal maupun non-formal. Demikian halnya dengan buku teks pelajaran sekolah memiliki peranan penting dalam pembelajaran, sehingga dalam 
penyusunan sebuah buku teks pelajaran harus ada beberapa aturan yang harus dipenuhi seorang penulis buku teks pelajaran.

Aturan-aturan tersebut telah dibahas secara rinci oleh Banda Standar Nasional Pendidikan (BSNP). Pentingnya buku dalam dunia pendidikan ternyata belum menjadi perhatian yang serius dari berbagai pihak yang peduli terhadap dunia pendidikan. Jamaludin, (2009: 211) menyatakan "dunia pendidikan buku sangat dibutuhkan sebagai sarana perkembangan ilmu pengetahuan dan teknologi. Buku merupakan piranti yang berperan penting dalam proses pembelajaran". Dapat diasumsikan, buku tidak dapat dipisahkan dari dunia pendidikan, karena buku sebagai media dan sumber pembelajaran serta buku teks atau buku ajar mampu mentransfer ilmu pengetahuan atau nilai-nilai kehidupan yang berkaitan dengan kompetensi dasar yang diajarkan.

Menurut Muslich, (2010: 50) buku teks pelajaran yang digunakan di sekolah-sekolah harus memiliki kebenaran isi, penyajian yang sistematis, penggunaan bahasa dan keterbacaan yang baik, dan grafika yang fungsional. Pada dasarnya, sebuah buku pelajaran yang baik adalah buku yang berfungsi sebagai alat pembelajaran yang efektif. Buku teks yang baik adalah buku pelajaran yang dapat membantu siswa belajar. Buku teks bukan hanya merupakan buku yang dibuka atau dibaca pada saat pembelajaran di kelas, melainkan dan inilah yang penting untuk dibaca siswa. Selain itu buku teks memiliki peranan penting bagi guru dan siswa selain sebagai bahan acuan pembelajaran dan sebagai sarana untuk membantu belajar siswa, buku teks juga membantu siswa untuk untuk memahami materi yang akan mereka pelajari dengan membaca dan memahaminya. Buku teks yang baik haruslah memiliki ayakan untuk dijadikan sumber belajar, yaitu menarik dan mampi merangsang minat siswa untuk mempelajarinya.

Menganalisis buku teks adalah salah satu cara yang baik dilakukan oleh guru agar dalat diketahui sejauh mana kualitas buku teks yang dipakai pada sistem pembelajaran. Berdasarkan Peraturan Menteri Pendidikan dan Kebudayaan No. 71 pasal; 1 tahun 2013 tentang Buku Teks, dalam Kurikulum 2013 ada dua buku yang digunakan sebagai buku teks acuan dalam pembelajaran, yakni buku teks pelajaran dan buku panduan guru. Buku teks pelajaran adalah sumber pembelajaran utama untuk mencapai kompetensi dasar dan kompetensi inti. Sedangkan buku panduan guru adalah pedoman yang memuat strategi pembelajaran, metode pembelajaran, teknik pembelajaran, dan penilaian untuk setiap mata pelajaran dan/atau tema pembelajaran.

Salah satu faktor penentuan keberhasilan siswa dalam menggunakan buku teks pelajaran ditentukan oleh kualitas buku teks pelajaran. Dalam pengukuran kualitas buku teks pelajaran harus diperhatikan aspek-aspek penting yaitu, kesesuaian isi dengan kurikulum, kebenaran isi, penyajian yang sistematis, penggunaan bahasa dan grafik yang fungsional. 
Keberhasilan pembelajaran yang ditentukan oleh kualitas buku teks pelajaran salah satunya adalah mata pelajaran Pendidikan Kewarganegaraan (PKn), PKn merupakan mata pelajaran yang diwajibkan untuk kurikulum dijenjang pendidikan dasar, menengah, atas dan mata kuliah wajib untuk kurikulum pendidikan tinggi, sebagaimana yang diamanatkan dalam Undang-Undang No. 20 Tahun 2007 tentang, Sistem Pendidikan Nasional pasal 37. Mengacu kepada Undang-undang tersebut artinya mata pelajaran PPKn tidak bisa dianggap tidak penting, karena mata pelajaran PKn merupakan mata pelajaran yang diwajibkan sehingga upaya untuk terus memperbaiki proses pembelajaran PPKn di sekolah harus terus ditingkatkan.

Meskipun buku teks Kurikulum 2013 pada mata pelajaran PPKn sudah dinilai kelayakan oleh Badan Nasional Sertifikasi Profesi (BSNP), namun peneliti melihat secara empiris ternyata buku teks mata pelajaran PPKn masih memiliki kekurangan, khususnya dari segi pemaparan materi yang cenderung terdapat pengulangan dari mater sebelumnya, selain itu isi materi dalam buku teks mata pelajaran PPKn terlihat materinya kurang menarik, sehingga cenderung bosan dalam proses pembelajaran. Situasi tersebut tidak boleh dibiarkan secara terus menerus sehingga dapat mempengaruhi hasil belajar siswa. Untuk itu diperlukan solusi berupa langkah inovatif dari guru PPKn dalam menguasai dan menyajikan materi ajar PPKn dari buku untuk lebih kreatif dan inovatif lagi sehingga siswa lebih bersemangat mengikuti pembelajaran.

Mencermati situasi tersebut, maka penulis tertarik untuk meneliti guna memperoleh jawaban dan informasi yang objektif mengenai “Analisis Buku Teks Kurikulum 2013 sebagai Sumber Belajar Pendidikan Pancasila dan Kewarganegaran pada Siswa Kelas VII SMP Negeri 2 Sayan Kabupate Melawi”.

\section{METODE}

Penelitian Ini Menggunakan Metode Penelitian Deskriptif Dengan Pendekatan Kualitatif (Sugiyono, 2012). Metode Deskriptif Digunakan Karena Dalam Penelitian Ini Akan Mendeskripsikan "Analisis Buku Teks Kurikulum 2013 sebagai Sumber Belajar Pendidikan Pancasila dan Kewarganegaran pada Siswa Kelas VII SMP Negeri 2 Sayan Kabupate Melawi”. Data penelitian dikumpulkan dengan menggunakan teknik wawancara, dan observasi, dan dokumentasi, dengan alat pengumpul data yakni, panduan wawancara, panduan observasi, dan dokumen.

Teknik analisis data dilakukan dengan langkah-langkah yaitu: reduksi data, penyajian data, dan penarikan kesimpulan. Peneliti menggunakan triangulasi teknik pengumpul data dan triangulasi sumber data untuk menjamin kredibilitas dari kesimpulan hasil penelitian (Sugiyono, 2012). 


\section{HASIL DAN PEMBAHASAN}

\section{Isi Materi Buku Teks Kurikulum 2013 Sebagai Sumber Belajar Siswa}

Konsep kurikulum 2013 mengacu pada pembelajaran PPKn secara terpadu dan utuh dengan menggunakan berbagai pendekatan sehingga setiap pengetahuan yang diajarkan, pembelajarannya harus dilanjutkan sampai membuat siswa terampil dalam menyajikan pengetahuan yang dikuasainya secara konkret dan abstrak (Kemendikbud, 2013). Dalam dunia pendidikan buku sangat dibutuhkan sebagai sarana perkembangan Ilmu Pengetahuan yang dimiliki oleh peserta didik. Buku teks merupakan piranti yang berperan penting dalam proses pembelajaran. Buku teks sendiri tidak dapat dipisahkan dari dunia pendidikan, karena buku teks sebagai media dan sumber pembelajaran serta buku teks atau buku ajar mampu mentransfer ilmu pengetahuan atau nilai-nilai kehidupan yang berkaitan dengan kompetensi dasar yang diajarkan

Perbedaan kurikulum 2013 dengan kurikulum sebelumnya yaitu adanya buku siswa dan buku guru yang telah disediakan oleh pemerintah pusat sebagai wajib sumber belajar di sekolah. Buku siswa dan buku guru menjabarkan usaha minimal yang harus dilakukan siswa untuk mencapai kompetensi yang diharapkan. Sesuai dengan pendekatan yang dipergunakan dalam Kurikulum 2013, siswa diberanikan untuk mencari dari sumber belajar lain yang tersedia dan terbentang luas disekitarnya (Kemendikbud, 2014).

Buku siswa telah disediakan oleh pemerintah dalam rangka implementasi Kurikulum 2013 yang telah disusun dan ditelaah oleh berbagai pihak dibawah koordinasi Kementerian Pendidikan dan Kebudayaan, dan dipergunakan dalam tahap awal penerapan Kurikulum 2013 (Kemendikbud, 2014). Buku guru adalah panduan bagi guru dalam melaksanakan pembelajaran di kelas. Buku guru juga digunakan oleh guru dalam kaitannya mengenai prinsip, prosedur, deskripsi materi pokok, dan model pembelajaran untuk digunakan oleh para pendidik.Buku guru merupakan buku yang dipersiapkan pemerintah dalam rangka implementasi Kurikulum 2013. Buku guru disusun dan ditelaah oleh berbagai pihak di bawah koordinasi Kementerian Pendidikan dan Kebudayaan, dan dipergunakan dalam tahap awal penerapan Kurikulum 2013 (Kemendikbud, 2014). Buku guru berisi informasi tentang metode dan teknik pembelajaran yang digunakan sebagai acuan penyelenggaraan proses pembelajaran. Salah satu faktor penentuan keberhasilan siswa dalam menggunakan buku teks pelajaran ditentukan oleh kualitas buku teks pelajaran. Dalam pengukuran kualitas buku teks pelajaran harus diperhatikan aspek-aspek.

Warsita, (2008:78). Sumber belajar adalah semua sumber baik berupa data, orang dan wujud tertentu yang dapat digunakan oleh siswa dalam dalam belajar, baik secara terpisah maupun secara terkombinasi sehingga mempermudah siswa dalam mencapai tujuan belajar atau mencapai kompetensi tertentu. (Mulyasa, (2013:112), Sumber belajar dapat memberikan kemudahan kepada 
siswa dalam memperoleh sejumlah informasi, pengalaman dan ketrampilan dalam proses belajar. Salah satu faktor penentuan keberhasilan peserta didik dalam menggunakan buku teks K-13 pelajaran ditentukan oleh kualitas buku teks pelajaran. Dalam pengukuran kualitas buku teks pelajaran harus diperhatikan aspek-aspek penting yaitu kesesuaian isi dengan kurikulum, kebenaran isi, penyajian yang sistematis, penggunaan bahasa dan grafik yang fungsional. Buku teks K-13 diharapkan dapat mengoptimalkan kegiatan belajar yang menyajikan bahan pelajaran yang bermakna. Buku teks mempunyai peranan yang penting bagi guru dan siswa sebagai acuan bahan pembelajaran. Buku teks K-13 memiliki penyajiannya harus menarik, menantang, materinya bervariasi sehingga siswa benar-benar termotivasi untuk memelajarinya. Semakin berkualitas suatu buku, semakin sempurna mata pelajaran yang ditunjangnya.

Berdasarkan penelitian yang dilakukan Saraswati, Agung, dan Sudarma, (2016: 1) tentang Analisis buku teks siswa kurikulum 2013 ditinjau dari aspek desain pesan pembelajaran kelas IV Sekolah Dasar, penelitian ini menyimpulkan bahwa, (1) kualitas buku teks siswa kurikulum 2013 ditinjau dari standa buku teks berada dalam kagori cukup, (2) kualitas buku teks siswa kurikulum 2013 dintinjau dari aspekn desain pesan teks berada pada kategori baik, dan (3) kualitas buku teks siswa kurikulum 2013 ditinjau dari aspek desain pesan gambar berapa pada kategori cukup. Penelitian yang dilakukan Pramana, Sriasih, \& Gunatama (2017: 1) yang meneliti tentang Analisis kesesuaian materi buku teks Bahasa Indonesia SMP/MTs Kelas VII dengan karakteristis siswa kelas A7 SMPN 1 Singaraja. Penelitian ini menyimpulkan bawah, (1) terdapat beberapa materi yang kurang sesuai pada penilaian autentuk kompetensi pengetahuan dan kompetensi keterampilan, dan (2) materi buku teks bahasa Indonesia SMP/MTs kelas VII Kurikulum 2013 edisi revisi 2017 sesuai dengan karakteristik siswa kelas VII A7 di SMPN 1 Singaraja, walaupun belum secara maksimal.

Berdasarkan hasil penelitian yang dilakukan diperoleh informasi bahwa, siswa memahamai isi materi buku teks PPKn Kurikulum 2013. Siswa dapat mempelajari fakta, konsep, prinsip, hukum, teori dan gagasan inovatif pada tingkat ingatan, serta siswa dapat menerapkannya secara efektif dalam pemecahan masalah dalam pembelajaran. Buku teks PPKn Kurikulum 2013 yang diterbitkan oleh Kementerian Pendidikan dan Kebudayaan berpusat pada tim penyusun yang dibentuk oleh Kemendikbud. Kebijakan pertanggungjawaban terpusat atas buku pegangan guru dan siswa diimplemtasikan untuk menanggulangi kesalahan penerbit-penerbit buku pelajaran.

Berdasarkan analisis yang dilakukan bahwa, isi dari buku teks PPKn Kurikulum 2013 ternyata cukup baik. Hal terlihat dari cara penyajian bahan ajar yang memperhatikan hierarki dan tata letak materi ajarnya. Materi buku disajikan secara menarik (runtut, koheren, lugas, mudah dipahami, dan interaktif), sehingga keutuhan makna yang ingin disampaikan dapat terjaga dengan 
baik. Ilustrasi materi baik teks maupun gambar menarik sesuai dengan tingkat perkembangan siswa di kelas rendah dan siswa di kelas tinggi. Buku teks PPKn Kurikulum 2013 juga mengandung wawasan kontekstual, dalam arti relevan dengan kehidupan keseharian serta mampu mendorong siswa untuk mengalami dan menemukan sendiri hal positif yang dapat diterapkan dalam kehidupan sehari-hari. Penyajian materi juga menarik sehinga isi buku teks terlihat menyenangkan bagi siswa untuk membacanya, dan dapat menumbuhkan rasa ingin tahu yang besar untuk belajar. Meskipun pada buku teks kurikulum 2013 pada mata pelajaran PPKn masih ada beberapa materi ajar yang cenderung mengulang pada pembahasanya, sehingga dapat mempengaruhi minta belajar dan ketertarikan rasa ingin tahu siswa akan cenderung rendah.

\section{Manfaat Buku Teks Kurikulum 2013 Sebagai Sumber Belajar Siswa}

Buku teks bagi seorang pelajar maupun seorang pendidik merupakan suatu kebutuhan yang harus dipenuhi dalam proses pembelajaran, karena buku teks itu sendiri sebagai sumber bahan ajar ataupun pegangan untuk saling melengkapi antara guru dan siswa. Buku teks merupakan salah satu alat yang digunakan dalam proses pembelajaran yang dapat mempermudah guru dan siswa. Buku teks K-13 berfungsi sebagai penunjang dalam kegiatan belajar mengajar.

Penelitian yang dilakukan oleh Efendi, (2015) tentang "Beberapa Catatan tentang Buku Teks Pelajaran di Sekolah". Efendi menyimpulkan bahwa, manfaat buku teks bagi siswa sangat penting, jika tujuan pembelajaran adalah untuk menjadikan siswa memiliki berbagai komptensi untuk mencapai tujuan tersebut, siswa perlu menempuh pengalaman dan latihan serta mencari informasi. Alat yang efektif untuk itu adalah buku pelajaran, sebab pengalaman dan latihan yang perlu ditempuh dan informasi yang perlu dicari, begitu pula tentang cara menempuh dan mencarinya, disajikan dalam buku pelajaran secara terprogram. Manfaat buku pelajaran bukan saja hanya bagi siswa, guru pun sangat terbantu. Pada waktu mengajar, guru harus mempertimbangkan pula apa yang tersaji dalam buku pelajaran. Guru tentulah memiliki kebebasan dalam memilih, mengembangkan, dan menyajikan materi. Semua itu merupakan kewenangan dan kewajiban profesionalnya. Ia memiliki pengetahuan tentang struktur keilmuan berkenaan dengan materi yang akan diajarkannya. Gurupun memiliki keterampilan dalam mengolah dan menyajikannya. Walaupun demikian, segala yang tersaji dalam buku pelajaran tetap saja berguna baginya, misalnya sebagai bahan untuk dipilih dan disusun bersama dengan bahan dari sumber lain. Juga cara penyajian dalam buku pelajaran dapat dijadikan sebagai contoh pada menyajikan bahan dalam kegiatan pembelajaram siswanya.

Berdasarkan hasil analisis mengenai manfaat buku teks Kurikulum 2013 bagi siswa kelas VII di SMP Negeri 2 Sayan Kabupaten Melawi bahwa, manfaat buku teks juga memberikan 
kesempatan kepada siswa untuk menyegarkan ingatannya mengenai materi yang sudah diajarkan, dengan begitu dia tidak mudah lupa. Buku teks yang berkualitas tentunya buku teks yang dapat dipahami dan dimengerti oleh siswa atau pemakai buku tersebut. Seandainya tingkat keterbacaan terhadap siswa itu rendah, maka buku tersebut perlu dikaji ulang. Keterbacaan kepada siswa memang berbeda-beda, maka dari itu sebelum buku dipublikasikan perlu diadakan pengujian baik melalui aspek keterbacaan dan tingkat keterbacaan terhadap siswa. Buku teks ini pula yang membantu siswa untuk memahami materi yang akan mereka pelajari dengan membaca dan memahaminya. Siswa termotivasi untuk belajar dengan adanya buku teks yang mampu merangsang minat untuk membacanya. Dengan adanya buku yang menarik, siswa akan mau belajar dan tertarik untuk memahami materi pelajaran. Selain itu manfaat buku teks PPKn Kurikulum 2013 dapat membantu siswa memecahkan masalah yang sederhana maupun rumit, sehingga tidak menimbulkan persepsi yang keliru pada siswa, serta isi buku teks PPKn Kurikulum 2013 dapat dipertanggungjawabkan kebenarannya sesuai dengan kaidah keilmuan.

Manfaat buku teks tidak hanya bagi siswa, tetapi guru pun dapat terbantu. Tujuan pengadaan dan pemanfaatan buku pelajaran memang diperuntukkan bagi siswa, akan tetapi, guru pada waktu mengajar dapat mempertimbangkan pula materi yang tersaji dalam buku pelajaran. Guru tentulah memiliki kebebasan dalam memilih, mengembangkan, dan menyajikan materi. Dalam proses belajar mengajar, guru harus memanfaatkan buku ajar secara optimal sehingga peserta didik dapat mengembangkan pengetahuannya. Pemilihan buku teks perlu mempertimbangkan beberapa hal diantaranya adalah adanya kualitas buku teks. Semakin baik kualitas buku teks, maka diharapkan akan semakin baik juga pembelajaran mata pelajaran.

\section{SIMPULAN}

Isi dari buku teks PPKn Kurikulum 2013 ternyata cukup baik, sebagaimana terlihat dari cara penyajian bahan ajar yang memperhatikan hierarki dan tata letak materi ajarnya. Materi buku disajikan secara menarik (runtut, koheren, lugas, mudah dipahami, dan interaktif), sehingga keutuhan makna yang ingin disampaikan dapat terjaga dengan baik. Ilustrasi materi baik teks maupun gambar menarik sesuai dengan tingkat perkembangan siswa di kelas rendah dan siswa di kelas tinggi. Buku teks PPKn Kurikulum 2013 juga mengandung wawasan kontekstual, dalam arti relevan dengan kehidupan keseharian serta mampu mendorong siswa untuk mengalami dan menemukan sendiri hal positif yang dapat diterapkan dalam kehidupan sehari-hari. Penyajian materi juga menarik sehinga isi buku teks terlihat menyenangkan bagi siswa untuk membacanya, dan dapat menumbuhkan rasa ingin tahu yang besar untuk belajar. Manfaat buku teks Kurikulum 2013 sebagai sumber belajar siswa kelas VII SMP Negeri 2 Sayan Kabupaten Melawi yaitu, 
memberikan kesempatan kepada siswa untuk menyegarkan ingatannya mengenai materi yang sudah diajarkan, dengan begitu dia tidak mudah lupa. Buku teks yang berkualitas tentunya buku teks yang dapat dipahami dan dimengerti oleh siswa atau pemakai buku tersebut. Seandainya tingkat keterbacaan terhadap siswa itu rendah, maka buku tersebut perlu dikaji ulang. Keterbacaan kepada siswa memang berbeda-beda, maka dari itu sebelum buku dipublikasikan perlu diadakan pengujian baik melalui aspek keterbacaan dan tingkat keterbacaan terhadap siswa. Dikarenakan buku teks ini pula yang membantu siswa untuk memahami materi yang akan mereka pelajari dengan membaca dan memahaminya. Siswa termotivasi untuk belajar dengan adanya buku teks yang mampu merangsang minat untuk membacanya. Dengan adanya buku yang menarik, siswa akan mau belajar dan tertarik untuk memahami materi pelajaran. Selain itu manfaat buku teks PPKn Kurikulum 2013 dapat membantu siswa memecahkan masalah yang sederhana maupun rumit.

\section{DAFTAR PUSTAKA}

Efendi, A. (2015) Beberapa Catatan Tentang Buku Teks Pelajaran di Sekolah. http://ejournal.iainpurwokerto.ac.id/index.php/insania/article/view/334 [diakses 22 Mei 2019]

Jamaludin, S. (2009) Model-Model, Media dan Strategi Pembelajaran Kontektual Inovatif. : CV. Yrama Widya

Kemendikbud. 2014. Konsep dan Implementasi Kurikulum 2013. Jakarta: Kementrian Pendidikan dan Kebudayaan

Mulyasa. (2013). Pengembangan Kurikulum di Indonesia 1947-2013. Jakarta: Prestasi Pustaka

Muslich, M. (2010).Text Book Writing. Dasar-Dasar Pemahaman Penulisan dan Pemakaian Buku Teks. Jakarta ISBN

Peraturan Pemerintah No.20 Tahun 2013 Standar Pendidikan Nasional: Jakarta Depdikbud Peraturan Pemerintah No.20 Tahun 2013 Standar Pendidikan Nasional: Jakarta Depdikbud Pramana, Sriasih \& Gunatama (2017). Analisis Kesesuaian Materi Buku Teks Bahasa Indonesia SMP/MTs Kelas VII dengan Karakteristik Siswa Kelas VII A7 di SMPN 1 Singaraja. EJournal Jurusan Pendidikan Bahasa dan Sastra Indonesia (Volume : 7 No:2 Tahun 2017). http://ejournal.undiksha.ac.id/index.php/JJPBS/article/download/14985/9131 [diakses 20 Mei 2019]

Sugiyono. (2012). Metode Penelitian Pendidikan. Bandung: Alfabeta

Saraswati, Agung \& Sudarma. (2016). Analisis Buku Teks Siswa Kurikulum 2013 Ditinjau dari Aspek Desain Pesan Pembelajaran Kelas IV Sekolah Dasar. e-Journal Edutech Universitas Pendidikan Ganesha Jurusan Teknologi Pendidikan (Vol: 5 No: 2 Tahun 2016.http://ejournal.undiksha.ac.id/index.php/JEU/article/download/7770/5303 [diaksess 21 Mei 2019] 